\title{
Hard-of-Hearing Individuals' Narratives of Inclusion and Exclusion of their Schooled EFL Learning
}

\author{
Narrativas de personas con dificultades auditivas sobre su \\ inclusión y exclusión en el aprendizaje del inglés como lengua \\ extranjera
}

\author{
Rigoberto Castillo ${ }^{1}$ \\ Laura-Stefany Flórez-Martelo ${ }^{2}$
}

\begin{abstract}
This paper deals with research on inclusion concentrating on the pedagogical implications derived from a qualitative case study that looked into three hard-of-hearing (HHs) students' perspectives and retrospectives on their schooled EFL learning. Data came from narratives gathered in autobiographical writings and interviews. Although there is a good body of literature on pedagogy in terms of strategies for dealing with HHs, few works have counted on the student's perspectives. The authors' insights, one of them being hard-of-hearing, call for truly inclusive policies and practices that address the categories developed in this case study, namely: 1. Deafness separates HHs from people. 2. Hearing aids are not like glasses, and 3. An exemption is not inclusion. The authors feel that the recommendations made are valid for learners with or without disabilities.
\end{abstract}

Rigoberto Castillo holds a Ph.D. and an M.A in Applied Linguistics from The University of Texas at Austin. Professor at Universidad Distrital, Colombia, and a member of the research group Formación de Educadores. Fulbright alumnus and recipient of the National Award of ASOCOPI. He serves on the Advisory Committee of several scientific journals. rcastillo@udistrital.edu.co

ORCID: https://orcid.org/0000-0002-9527-0120

2 Laura-Stefany Flórez-Martelo holds a B.A. in Education from Universidad Distrital, Colombia where her research work received recognition. Currently works in Texas. Recipient of the Turkish Language School Scholarship. She has published and participated in conferences to advocate for inclusion and debunk the myths and misconceptions about hard-of-hearing individuals, like herself.

lsflorezm@correo.udistrital.edu.co

Received: April 12th, 2020. Accepted: August 6th, 2020.

This article is licensed under a Creative Commons Attribution-Non-Commercial-No-Derivatives 4.0 International License. License Deed can be consulted at https://creativecommons.org/licenses/by-ncnd/4.0. 
Rigoberto Castillo

Laura-Stefany Flórez-Martelo

Keywords: foreign language, hard of hearing, inclusion pedagogy, inclusion policies, learning rights, special education

\section{Resumen}

Este artículo reporta una investigación cualitativa de estudio de caso sobre inclusión que indagó las perspectivas y retrospectivas de tres estudiantes hipoacúsicos sobre su aprendizaje del inglés en las aulas. Los datos provinieron de narrativas registradas en entrevistas y escritos autobiográficos. Las recomendaciones pedagógicas son igualmente válidas para estudiantes sin deficiencias auditivas. Aunque hay bastante literatura sobre pedagogía para los hipoacúsicos, pocos cuentan con la perspectiva de los afectados. La mirada de los autores de este artículo, una de ellas hipoacúsica, hacen un llamado a políticas y prácticas incluyentes que están contenidas en las categorías de este estudio de caso: 1. La sordera separa a los hipoacúsicos de la gente. 2. Las ayudas auditivas no son como los anteojos y 3. Una exoneración o excepción no es inclusión.

Palabras clave: educación especial, derechos básicos de aprendizaje, hipoacusia, inclusión lenguas extranjeras, políticas de inclusión

\section{Introduction}

Our inquiry puts a piece of a puzzle in the landscape of hard-of-hearing individuals (HHs). There was a piece missing: the students' perspectives and retrospectives on their schooled learning. The general objective of this research study was to understand how three hard of hearing participants made sense of their L2 learning. The specific objectives were to make recommendations supported by data. Three participants from 18 to 25 years old, who took English as a foreign language (EFL) in integrated classrooms, joined the inquiry. The setting of the study was at Mediglobal I.P.S., a private medical institution specialized in hearing loss (Consent form in Appendix D). One of the authors of this paper, with a hard-of-hearing condition herself, did volunteer work there. The qualitative case study used autobiographical narratives (Appendices A and B) and interviews (Appendix C). For clarity, the authors of this article paraphrased in English the excerpts of the participants' narratives cited in Spanish.

Some of the key aspects of the condition of hard-of-hearing individuals (HHs) provide a background. Hearing loss distorts the mode in which people perceive words. Most HHs cannot hear word endings such as $-s$ or $-e d$. This wrong discernment disturbs

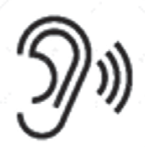
verb tenses, plural forms, non-agreement of subject and verb, and possessives (ASHA, 2005). It affects L2 learning because the HHs find it challenging to identify suffixes that add meaning to words. Furthermore, there is an inability to perceive voiceless sounds such as $/ f /, / \mathrm{k} /, / \mathrm{p} /, / \mathrm{s} /, / \mathrm{J} /, / \mathrm{t} /, / \mathrm{t} /$, and $/ \theta /$ which, in turn, are omitted in speech. 
Additionally, HHs may not hear their voices when they speak so they may seem too loud or not loud enough, or as if they were mumbling because of poor stress, poor inflection, or poor pace of speaking. This limitation is not a predictor of success or failure. They need the support of schools and homes teaming up to facilitate language acquisition and enhance their academic achievement. Although the diagnosis of impairment is mandatory to prevent delay in language acquisition, some institutions fail to comply with this.

Laws and declarations aim toward more inclusive education; however, in several communities, these demands are unreachable. The perspectives and retrospectives collected from HHs prompted the recommendations given for EFL teaching/learning under the umbrella of the categories that emerged. Their voices constituted layers of understanding of the struggles of other individuals with disabilities.

\section{Method}

This study employed grounded theory and case study. Discussing qualitative research, Laws and McLeod (2020) explain that by combining methods, advantages of each methodology complement one another, and make for stronger design and results, and more valid and reliable findings. The analysis of the participants' perspectives suited a case study method since "qualitative research is characterized by an interpretative paradigm which emphasizes subjective experiences and the meanings they have for an individual" (Rebojli, 2013 , p. 30). This is consistent with our purpose of exploring the HHs' views from a personal dimension of experience for building meaning and understanding of how they made sense of their L2 acquisition.

For Alzaanin (2020, p. 1367), "Case study design promotes the collection of rich data from multiple sources and the constructivist grounded theory approaches to data analysis enable researchers to generate theoretical models from within the data". This approach allowed us to gather and analyze data simultaneously. We collected discourses in autobiographical narratives and interviews (see Appendices) from the perspectives and retrospectives of three actors, the hard-of-hearing individuals. From official documents, we also reported the discourses of those who designed the policies.

The three participants were named after well-known HHs: Edison for the inventor Thomas Alva Edison, Clinton for U.S. President Bill Clinton and Ludwig for van Beethoven. Table 1 summarizes their characteristics. The diagnoses of the participants occurred in their early childhood, and included technical and medical support. They communicated orally; never learned sign language. They went to integrated schools where they took EFL in Colombia and later on stayed in English-speaking countries. 
Table 1

Characterization of the Participants

Participant One: Edison

Age: 26 years old

Age at time of diagnosis: 1-year-old

Diagnosis: Profound bilateral hearing loss

Technical help: Cochlear Implant both ears

Language Therapy: Yes.

The main form of communication: Oral language

Sign language: No

Level of Education: Mechanical Engineer

English level: B1 Certified. He took 500 hours of English in a language school.

Six months of English course in the U.S.

Participant two: Clinton

Age: 20 years old

Age at time of diagnosis: 3 years old

Diagnosis: Profound hearing loss in the left ear, severe hearing loss in the right ear.

Technical help: Hearing aids

Language Therapy: Yes

The main form of communication: Oral language

Sign language: No

Level of Education: undergraduate industrial design student $2^{\text {nd }}$ year

English Level: B1 certified

One year study of English in New Zealand

Participant three: Ludwig

Age: 18 years old

Age at time of diagnosis: 3 years old

Diagnosis: Profound bilateral hearing loss.

Technical help: Hearing aids and cochlear implant

Language Therapy: Yes

The main form of communication: Oral language

Sign language: No

English Level: B1 certified -10 years at a Bilingual School

Level of Education: Freshman in economics

In the sessions for data collection, participants did autobiographical writings and related their experiences in interviews. The HHs' perspectives and retrospectives on their schooled L2 learning appear in the narratives gathered. As Guerrero (2011) states, "Narrative is a system of understanding that we use to construct and express meaning in our daily lives" (p. 89).

HOW Journal 


\section{Data Analysis and Results}

Following grounded theory principles, the data collection and analysis became interrelated and guided the exploration. Coding of data analysis and filtering emerging categories met the objective of establishing the categories, which underwent a transformation, reduction, and simplification (Creswell, 2007). For interpreting, we compared and simultaneously coded the data to develop concepts, identify data incidents, properties, similarities, differences, and interrelationships. In this process, we spotted patterns that triggered the emergence of the main categories that denote the factors that influence the HHs' struggles and achievement with the foreign language (FL).

The resulting categories were: (1) Deafness separates us from people, a reality which refers to the social dimension that needs to be understood by educational communities, (2) Hearing aids are not like glasses, which addresses misconceptions about hearing loss, and (3) an exception is not inclusion, which raises doubts on the policies and practices of inclusion in the educational sector. The categorization allowed building systematically a deeper understanding of the participants' experiences and perspectives, as well as patterns of behavior related to the problem for explaining how the HHs made sense of their L2 learning.

Participants deemed the support of the school staff, classmates, and relatives to be crucial. Additionally. they also reported that some practices like listening exercises and tests with loudspeakers --via CD's or television screens-- did not allow them to understand; they also declared that teaching and testing in this way were unfair. They spoke of the discrimination in policies and reporting of their scores on standardized national tests.

\section{Category 1. Deafness Separates Us from People}

HHs tend to feel more isolated because their condition separates them from others due to misunderstandings or prejudice. Helen A. Keller who was the first deaf-blind person to earn a university degree affirmed that blindness separates us from things but deafness separates us from people. The testimonies of the participants went in that direction. Ludwig detested that his classmates perceived him as someone distant, weird, or resented. In his words:

"Mis compañeros de clase me ven como alguien que los tiene alejados. Extraño, pues ellos perciben que los odio, detesto un sinnúmero de vainas. Da rabia haber generado esa percepción”. (Appendix E, structured interview)

Regarding social isolation and self-concept, the three participants declared that at school, they made extra efforts to be accepted. Thus support is essential for every student with or without a limitation or disability. HHs understand their struggles and instructors need to be open to suggestions that reduce anxiety. Edison declared: 
Rigoberto Castillo

Laura-Stefany Flórez-Martelo

"The [English] teacher was talking, talking, talking all the time, and all my classmates understood. The teacher got angry because I did not understand, and he continued talking, talk, and talk, and I didn't understand anything. And I wanted to go out but I couldn't because the teacher was at the door so... it was scary for me in general”. (See Appendix C. Excerpt from group interview, English original)

Frustration and isolation derive from the lack of support or underestimation, especially in an attempt to learn an L2. Segregation comes from the prejudices and doubts about the learners' capacity to do things.

\section{Category 2. Hearing Aids Are Not like Glasses}

Some affirm that wearing glasses can make people look 'intellectual' while wearing a hearing aid makes them look impaired. This could explain some people's low expectations and negative attitudes towards HHs. Hearing aids (HAs) are not like glasses, and once one wears a HA, her/his hearing is NOT restored to normal. HAs make all kinds of soundsincluding picking up background noises-louder but not always clearer, making it difficult for the HA wearer to understand speech. The underlying beliefs of a community lead to segregation. Clinton remembered one day his batteries ran out and he had no spare ones, so he could not hear or understand much. But his teachers were not very cooperative when he asked them to speak louder. About this aspect, Edison mentioned that:

"When I got my first hearing aids I learned to speak, but somehow I did not speak, well since my classmates looked at me strangely. I eventually got used to it until I got my first friends and they accepted me as I was". (Appendix F. Autobiography extract, Spanish original)

Furthermore, Edison mentions misconceptions:

"Classmates sometimes ask, me what I have in my ears; then I tell them that I cannot hear, and then they say, ah so you speak sign language, and I say, No, I was never taught signs. Sometimes people ask me to take off my hearing aids to check, that I cannot hear, and then I tell them that obviously, I am not going to hear".

Ludwig used a strategy to manage:

"Let's say that what I did first always was to help my classmates understand and know very well what I face, what happens to me, and what can happen to me." (Appendix C. Excerpts from group interview, Spanish original)

The extracts above exemplify the importance of educating others to recognize hearing loss, understand its implications, and learn to support the HHs. The educational community should be informed that hearing aids have a limitation for the discrimination of speech from tracks or loudspeakers or even for natural conversations. Along those lines, Jambor and Elliott (2005) state that: 
HHs often need further cues, such as face-to-face communication with constant eye contact, lip-reading, and understanding body language. Since these are rarely completely available in encounters with hearing people, deaf individuals are likely to lose a lot of information during the communication process. Even the use of hearing aids cannot fully solve the problem since these assistive devices cannot make other people's speech clearer, only a bit louder. (p. 66)

In contrast, HHs with the help of their residual auditory capacity acquire the mother tongue as L1 and another language as L2, but the obstacles in communication are permanent in both. Marschark, Spencer, Adams, and Sapere (2011) explain that HHs, rely on visuospatial processing. They require more visual than auditory stimuli for their cognitive development. In this respect, the three participants coincided that the use of recorded material and loudspeakers was too hard to understand and that their instructors continued using them with the HHs despite their complaints. This denied access to the information and insertion in the schoolroom dynamics.

\section{Category 3. An Exemption Is Not Inclusion}

The Ministry of Health of Colombia (Ministerio de Salud, 2016, p. 77) indicated that the statistics from 2009 to 2016 about medical consultation related to hearing showed that $27 \%$ corresponded to hard-of-hearing and that numbers are increasing. Similarly, the Ministry of Education of Colombia (M.E.N., 2017, p. 25) informs "that $12 \%$ of the cases reported with a disability do not have a clear diagnosis" and that $20 \%$ of students with a disability drop out of the system. These figures suggest the need for implementing pedagogical strategies, follow-up, and assessment for this particular population. The same document mentions that $4 \%$ of the registration in primary and secondary schools are hard-of-hearing individuals.

The HHs cannot fully function as hearing in a world that relies on hearing and speech and in classrooms that do not make adaptations. Teacher-centered practices and normative quantitative evaluation of learning do not help. These may lead to frustrating experiences and diminished self-regard (self-esteem) (Jambor \& Elliott, 2005). For example, in the narrative of Appendix A, Clinton affirms that when he went to a large school the noise was unbearable and classmates could not understand why he spoke 'foreign'.

The three participants mentioned that most of their EFL teachers exempted them from doing listening tasks or tests that used recordings. However, they saw no efforts of offering work on listening with face to face interaction or adjusting materials for them which signals inequity in the classroom. Clinton affirms in the interview:

"When I see a track transcription, I can understand 100\% of the conversation, because I am reading. But I had like homework, like practice listening, a lot of tracks to improve my skills to listen to the tracks. Anyway, it still will be difficult." (Appendix C. Excerpts from group interview, English original) 
Rigoberto Castillo

Laura-Stefany Flórez-Martelo

Both the regular student and the HHs would benefit from a healthy environment and an opportunity to develop their competencies. Any exception or exemption should be a barrier to discrimination. School staff that relies on this defense should act accordingly. Beyond school boundaries, the organization that administers national standardized tests, ICFES, had failed to take affirmative action. It expressed that those who, due to a proven diagnosis, present limitations to learning foreign languages will be excluded from taking that section of the standardized exam and their results excluded from aggregated scores. For ICFES (2018, p. 10), "Este informe no considera los resultados de los estudiantes en condición de discapacidad puesto que estos son excluidos en los resultados agregados." Although HHs take English and have the ability to demonstrate that they learned it, their scores are not included in the high school leavers' (graduates') national test or the undergraduate exit exam.

The English tests section of the national exams Saber 11 and Saber Pro do not test listening. Hence, exempting HHs to take this exam does not have a solid basis, it is rather a bias that reflects the limited expectation governments have of them. Paradoxically, to obtain the high school or the undergraduate degree, HHs must achieve a level of FL proficiency. Exempting them from the requirement with the excuse of incapability is a mistake. In the scoring of standardized national exams for school leavers (Pruebas Saber 11) and (Saber Pro) for college leavers, the scores of HHs do not count. The testing organization does not take into account the English section in the added scores. Testtakers with special conditions become invisible and cannot access potential benefits like student loans since they do not appear in the official score records. These facts echo the isolation already described in the school system.

When Clinton took Saber 11, he registered as a regular student; with a sense of humor, he said he did not want to be remitted to a 'sign language college', for he did not know sign language. He was aware of the stigma and if registered with a disability, it would be to his disadvantage. His actual words in Spanish were: "No, ja, ja regular, porque si lo hacia, por la discapacidad, me mandaban a una universidad con lengua de señas."

Ludwig, on his part, argues that excluding students from taking the English test goes against public policy. Edison concurs that examining bodies limit opportunities for the HHs:

"Me parece que es una discriminación pues ellos no saben de qué es capaz la persona, que puede hacer, o sea hablar, escuchar, todo, así que tenemos el derecho de presentar todo, todo lo que está abí." (Appendix C. Excerpts from group interview, Spanish original)

In 2019, one of the writers of this paper took Saber Pro and registered as a HH individual because she was concerned about probably not being allowed to use her hearing aid during the examination. On the day of the test, her classroom had all of HHs test-takers, but the proctor did not have any idea of this; this person asked the group if an interpreter of sign language was needed, which was not the case. This episode relates to Ludwig's narrative, in 
which he complained that $\mathrm{HH}$ s are not treated as equals, nor given appropriate conditions, or allowed to take all of the sections of tests and compete with regular students:

'Deberían tratarte en iguales condiciones al resto de los demás que presentan la prueba, Además deberían garantizar que estés en el ambiente adecuado para presentarla. Debes seguir insistiendo en que te permitan presentar la prueba sin limitaciones, ni impedirte competir a un mismo nivel con personas que no tengan ningún tipo de discapacidad." (Appendix C. Excerpts from group interview, Spanish original)

Test administrators fail to consider that students with auditory difficulties do not always need an interpreter but need other adaptations; for example, explaining to the person in charge of transmitting the dynamics of the exam how to make sure the information should be delivered properly.

The scores of the test-takers with a special condition do not count in the statistics, they cannot appear in the honors list of Saber Pro, and then they cannot apply for government financial aid. Communities should take positive steps to help disadvantaged groups by using special measures. When an exception, exemption, or special measure discriminates, that goes against the policy, then against the law. For instance, Saber Pro, the college leavers' standardized test does not include the score of the English section of the test because of the $\mathrm{HH}$ condition, even if the taker is an English major.

The data gathered suggest that there are difficulties derived from policymakers', administrators' and teachers' lack of understanding of HH's needs. They need to enter into a dialogue with the students and their families to identify ways to facilitate coping with school duties and with standardized tests given the students' particularities and concerns. Fortunately, late in 2019, the Constitutional Court ruled that the testing organization, ICFES (2019), had to adjust the application of the tests to guarantee the participation of students with a reported disability. This report should not impede them to choose (i) the type of exam, (ii) the adjustment and support, and other favorable conditions to take the test, and (iii), taking or not taking the section of the English test:

La Corte Constitucional, en la Sentencia T-039 de 2019, ordenó al ICFES que mediante el procedimiento que la entidad considere pertinente, ajuste el proceso de inscripción de los exámenes de Estado, a fin de que este permita la participación de los estudiantes reportados con alguna de las condiciones de discapacidad, con el propósito de que el reporte de discapacidad no les impida poder elegir (i) el tipo de examen a aplicar, ya sea que este consista en el cuadernillo especial o el estándar; (ii) los ajustes, apoyos y otras condiciones de presentación del examen; y (iii) la presentación o no de la prueba de inglés. (p. 4)

This paper calls for school districts and educators to follow suit to change the rules, regulations, and practices of exclusion. It requires gaining knowledge of the psychological and social functioning of the deaf and hard-of-hearing individuals (D/HHs) as expressed in Dogamala-Zyśk and Kontra (2016). 
Rigoberto Castillo

Laura-Stefany Flórez-Martelo

\section{Discussion and Recommendations}

To sensitize audiences to see that recommendations go beyond instruction, data were grouped into three categories, namely: Deafness separates us from people, Hearing aids are not like glasses, and An exception is not inclusion. ASHA (2005) says that hearing loss causes a delay in speech and language, reduces academic achievement, and results in social isolation and poor self-concept. The first recommendation relates to the isolation that hearing-impairment causes to which schools should become sensitive and make efforts to understand the HHs' needs through dialogue. The involvement of the school community to become truly inclusive should be on the agenda. Instructors should notice students' struggles and accompany HHs in walking the extra mile and helping them build rapport with classmates and school staff.

Teachers need the training to adapt teaching techniques to monitor the learning process and achievement, and to guide the HHs' classmates in avoiding chatting or noisy situations that reduce hearing capacity. Teachers should promote silence as a sign of awareness and respect towards HHs. Awareness, dialogue, and trust should unite the HHs to other people.

The second recommendation is that instruction should be multimodal and multisensory. Even if HHs wear a hearing aid to figure out messages, they require analyzing the environment, the facial expressions, how people talk, and the tone of voice, the behavior, the movements, the place and the moment. Therefore, receiving information through more than one perception channel benefits not only the HHs but the regular students. Marschark et al. (2011) claim that teachers "need to guide D/HH cbildren's visual attention towards information targets, explaining their importance if necessary, in order to provide them with full access to instruction" (p. 25). This recommendation is in line with the institutional support, meaning that schools provide equipment and adaptations of the spaces. The noisy environment represents a challenge. Dogamala-Zyśk (2013) suggests adapting the schoolroom by softening floors with carpets and walls with soft coverings. Keeping HHs close to the speaker proves useful as well.

The third recommendation goes to educational organizations, policymakers, teachers, and society in general. Inclusion demands to adjust policies, spaces, teaching approaches, and assessment. For example, examining boards should offer a face to face interaction for the listening section, and it makes up part of the overall score as the standardized international TOEFL exam does. This is a lesson to be learned by other communities of practice in the EFL profession. For teaching and testing, the participants considered the selection of materials necessary. For example, the use of audio tracks alone has proved inadequate (Appendix C). Materials should provide high contextualization through images, figures, and background information to facilitate understanding, remembering, and recalling (Castillo, 2008).

Similarly, classroom adjustments in terms of visibility of the speakers, places, and situations provide information that allows learners to get the gist of a conversation or message. 
For instance, the pedagogical adjustments entail accompanying texts with visual support that also benefits regular students in terms of meaningful and contextualized interactions. Classroom accommodations to reinforce speech comprehension and noise reduction are crucial; both the interference from outside, and from inside the classrooms. For better communication, instructors should stand in front of the class, in a visible position close to the $\mathrm{HHs}$, and avoid moving around the classroom during the explanations. The position of the instructor and classmates needs to be within a distance that allows lip reading. These recommendations coincide with Dogamała-Zyśk (2013) and Dogamała-Zyśk and Kontra (2016), who identified effective techniques to teach the deaf or HHs. These authors also recognized that shouting does not help $\mathrm{HHs}$ at all; articulating, pausing between sentences, repeating, rephrasing, and writing key concepts do.

For example, the Americans with Disabilities Act of 2013 declares that discrimination undermines efforts by people with disabilities to receive an education. The ADA (2020, p. 3) lists some of the auxiliary aids and services to ensure effective communication with individuals who are deaf/hard of hearing or who are blind/have low vision, to wit:

Qualified interpreters on-site or through video remote interpreting (VRI) services; note-takers; real-time computer-aided transcription services; written materials; exchange of written notes; telephone handset amplifiers; assistive listening devices; assistive listening systems; telephones compatible with hearing aids; closed caption decoders; open and closed captioning, including real-time captioning; voice, text, and video-based telecommunications products and systems, including text telephones (TTYs), videophones, and captioned telephones, or equally effective telecommunications devices; videotext displays; accessible electronic and information technology; or other effective methods of making aurally delivered information available to individuals who are deaf or hard of hearing.

Breaking down barriers and misconceptions about disabilities enables societies to benefit from the skills, talents, and contributions of $\mathrm{HHs}$ and leads to fuller, more empathetic, solidary, and productive lives for all. The M.E.N (2016) acknowledges that basic learning rights should offer an umbrella of protection to guarantee equity and thus developed a guide to comply with. After the expedition of the Government Decree 1421 of 2017, the Ministry of Education issued a guide for attending students with disabilities (M.E.N. 2017). However, the narratives of the three participants and the work conducted by one of the authors at Mediglobal coincide that the promise of equal education is far from implementation, and hard-of-hearing remains an invisible disability.

The recommendations identified in this inquiry derived from several disciplines. Avila (2011) proposed Blended Learning to deal with the visual and written necessities of the deaf. Szymanski, Lutz, Shahan, and Gala (2013, p. 4) reported "Inadequate understanding by educators of what it takes to have a fully accessible, linguistically rich environment," while 
Rigoberto Castillo

Laura-Stefany Flórez-Martelo

Mapepa and Magano (2018, p. 5) claimed that support to schools in organizing, training and provision of adapted teaching materials is important:

This study recommends that adapted books and materials be available to facilitate learning across all subjects. These books and materials would encourage visualization... This study recommends that there is a need for schools to have non-teaching professionals within the school setting to support [the] social, emotional, career, spiritual and physical needs of learners.

Participants also felt they had to advocate as regards their educational rights and access to opportunities by demanding respect and inclusion. They recalled what helped them learn, and they would like to see enhanced educational practices in integrated classrooms. Exploring the perspectives and retrospectives of three individuals helped us identify critical aspects of teaching that are useful not only for HHs but for regular students.

According to the pieces of evidence gathered, the promises of the Ministry of Education of Colombia have fallen short. The M.E.N. (2007) spoke of moving from integration to inclusion by providing information and training that encompass not only intangible support but also the access to the equipment, resources, and personnel that are valuable in supporting schools. Institutions, policymakers, teachers, and all of society need to understand that inclusion does not mean excepting but adapting. Actual equity is achieved by adapting spaces, materials, teaching, and assessment. The reduction of noise, the provision of high contextualization, and visual support facilitate learning. Along those lines, Ochoa, Angulo, \& Aparicio (2017) called for an inclusive educational model in Colombia by supporting the design of a curriculum for pupils with linguistic and affective needs.

This inquiry heard authorized voices that struggled with adaptation, exclusion, and disrespect, because of their disability. The episodes in the narratives suggest the need to destigmatize hearing impairment by promoting knowledge about it as well as emphasizing the importance of a pedagogy that provides emotional support and care to enable succeses in an integrated classroom. This work constitutes an approximation to the perspectives and retrospectives of a group of HHs. This constitutes a study of relevance to contextualize and make visible a situation that can no longer be ignored.

Readers interested in a full discussion of the case study should refer to the publication by Florez-Martelo (2019) whose findings are summarized here. (1) HH individuals felt capable of mastering another language in integrated classrooms, (2) cognitive, affective, and social support contributed to the HH's school success, and (3) Educational institutions should provide training and resources to support the $\mathrm{HH}$.

Since this paper centered on the HHs' perspectives, its scope did not comprehend the discourse of the educational administrators who execute the policies. The readership interested in such analysis can refer to Gónzalez-Portillo and Jaraiz-Arroyo (2020) who 
compared the voices of politicians and technicians on inclusion. On the other hand, readers may refer to Avila (2011), who discusses web resources for promoting a collaborative atmosphere in a flexible learning environment, while Tilano-Vega et al. (2014) review human tools, software, televised tools, cochlear implants, and recognition systems.

\section{Conclusions}

This case study discussed and analyzed three individual cases and characterized the actors and the recollection of their L2 events, as well as a discussion of how they would like to see L2 taught in schools. The analysis of the participants' narratives shed light on the understanding of how HHs made sense of their L2 learning in regular classrooms, which was the objective of this study. The recommendations the participants made and the corresponding literature helped achieve the specific objective of applying the new knowledge to current practices. Accordingly, the evidence indicated that the three proactive HHs perceive L2 learning as a process in which they develop strategies to cope with the multiple misconceptions of their real needs. The main standpoints of this study are:

- First, the misconceptions and prejudices isolate the HHs more than the deafness itself. These come from the lack of knowledge and understanding of the condition that triggers misinterpretation of the real needs of the students that experience hearing loss. Listening to them is key to understanding their individualities, expectations, and necessities.

- Second, HHs require community support. HHs try to interact in the hearing world, however, the communities need to adapt to the hearing loss as well. This adaptation cannot rely on hearing devices but in facilitating communication through the multiple strategies available for this means.

- Third, an exemption is an exclusion. Inclusive practices need to point out to adaptation instead of an exemption, especially when this exoneration is based on misconceptions regarding HHs' capacities resulting counterproductive. Practices and policies must no longer turn around this. Finally, point out that inclusion is a matter of listening more instead of just hearing.

\section{References}

ADA (2020). The Americans with disabilities act questions and answers. https://adata.org/guide/americans-disabilities-act-questions-and-answers

Alzaanin, E. I. (2020). Combining case study design and constructivist grounded theory to theorize language teacher cognition. The Qualitative Report, 25(5), 1361-1376. 
Rigoberto Castillo

Laura-Stefany Flórez-Martelo

ASHA (2005). American Speech-Language-Hearing Association. Effects of hearing loss on Development. https://www.asha.org/public/hearing/Effects-of-Hearing-Loss-on-Development/

Castillo, R. (2008). Issues involved in context, comprehension and content. Latin American Journal of Content and Language Integrated Learning, 1(1), 15-25. https://doi.org/10.5294/laclil.2008.1.1.2

Avila, O. L. (2011). Teacher: Can you see what I'm saying?: A Research experience with deaf learners. Profile: Issues in Teachers 'Professional Development, 13(2), 131-146.

Creswell, J. (2007). Qualitative inquiry and research design: Choosing among five traditions. Sage.

Domagała-Zyśk, E. (2013). English as a foreign language for deaf and hard of hearing persons in Europe. Wydawnictwo Kul.

Dogamała-Zyśk, E., \& Kontra, E. H. (2016). English as a foreign language for deaf and hard of hearing persons: Challenges and strategies. Cambridge Scholars Publishing.

Florez-Martelo, L. E. (2019). Hard of hearing students' perspectives and retrospectives on

their schooled foreign language learning. [Unpublished monograph]. Universidad Distrital Francisco José de Caldas, Bogotá, Colombia.

González-Portillo, A., \& Jaraíz-Arroyo, G. (2020). Las políticas de inclusión social en Andalucía desde la perspectiva discursiva y lexicométrica. Un análisis comparativo del discurso técnico-político. EMPIRIA, Revista de Metodología de Ciencias Sociales, 45, 75-111. https://doi. org/10.5944/empiria.45.2020.26305

Guerrero, A. L. (2011). Narrative as a resource for the display of self and identity: The narrative construction of an oppositional identity. Colombian Applied Linguistics Journal, 88-99.

ICFES (2018). Informe nacional de resultados Saber Pro 2016-2017.

ICFES (2019). Resolución 675 de septiembre 4 de 2019. Por la cual se reglamenta el proceso de inscripción a los exámenes que realiza el ICFES.

Jambor, E., \& Elliott, M. (2005). Self-esteem and coping strategies among deaf students. Journal of Deaf Studies and Deaf Education, 10(1), 63-81.

Laws, K., \& McLeod, R. (2020). Case study and grounded theory: Sharing some alternative qualitative research methodologies with systems professionals.

M.E.N. (2017). Ministerio de Educacion Nacional. Guía para la implementación del decreto 1421 de 2017 atención educativa a personas con discapacidad en el marco de la educación inclusiva. http://aprende.colombiaaprende.edu.co/ckfinder/userfiles/files/Guia $\% 20 \mathrm{de} \% 20$ ароуо $\% 20$

M.E.N. (2016). Ministerio de Educacion Nacional. Suggested Curriculim for English. https:// www.mineducacion.gov.co/1759/articles-360293_foto_portada.pdf

M.E.N. (2017). Ministerio de Educacion Nacional. Documento de orientaciones técnicas, administrativas y pedagógicas para la atención educativa a estudiantes con discapacidad en el marco de la educación inclusiva. At https://www.mineducacion.gov.co/1759/w3-article-360293. html?_noredirect=1

M.E.N. Ministerio de Educacion Nacional. (2007). Al tablero No. 43, septiembre-diciembre. 
Mapepa, P., \& Magano, M. D., (2018). Support to address barriers to learning for learners who are deaf. African Journal of Disability, (7), 1-8. https://doi.org/10.4102/ajod.v7i0.381

Marschark, M. M., Spencer, P. E., Adams, J., \& Sapere, P. (2011). Teaching to the strengths and needs of deaf and hard-of-hearing children. European Journal of Special Needs Education, 26(1), 17-23. https://doi.org/10.1080/08856257.2011.543542

Mediglobal IPS. (2016). Mediglobal IPS, especialistas en audicion y equilibrio. http://www.mediglobal. co/conocenos/

Ministerio de Salud (2016). Análisis de situación de la salud auditiva y comunicativa en Colombia. https://www.minsalud.gov.co/sites/rid/Lists/BibliotecaDigital/RIDE/VS/PP/ENT/asissalud-auditiva-

Ochoa, D., Angulo, J., \& Aparicio, L. (2017). Inclusión social de la población con limitacion auditiva en la educacion superior colombiana. Revista Logos de Ciencia y Tecnologia, 9(1), 197-209.

Rebolj, B. (2013). The case study as a type of qualitative research. Journal of Contemporary Educational Studies, (1) 28-43.

Szymanski, C., Lutz., L., Shahan, C., \& Gala, N. (2013). Critical needs of students who are deaf or hard of hearing. Laurent Clerc National Deaf Education Center, Gallaudet University.

Tilano-Vega, L. M., et al. (2014). Tools facilitating communication for the deaf. Educación y Educadores. 17(3), 468-480. 
Rigoberto Castillo

Laura-Stefany Flórez-Martelo

Appendix A. Clinton's autobiographical writing sample.
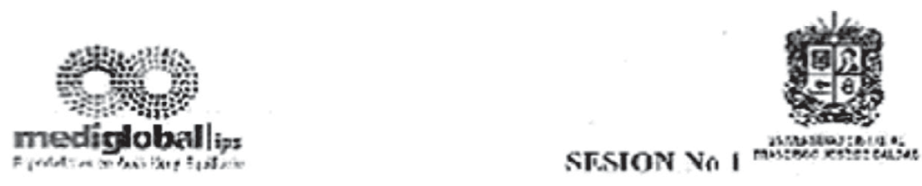

Cuéntame sobre ti:

A continuación puedes coutarnos sobre ti, puedes compartir lo que tu tlesees, anfar cxperiencius a cxerihir una breve autobiografta.

Mi numbre es ". ." 'tengo 20 años y me

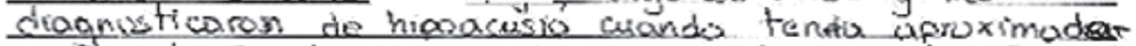
mente de 3 a 4 años, ex aso momento no entundía nuda pero cuando ture mis primens suditonos, aprendi a hablor pere de alguna forma no hublabo bien ya que mis compontens del colege me mimbon oxtmaño, con el Fiempis me acosturabre haster que twive mis primenus ómigas y me aceptaton como sixy.

Estudié hosta cuarto de primario en un colegio pequeño (coso), desde qunto grado me cambié a cto calegio y fue wa gran reto axis $\mathrm{mi}$ in que ero en otro ambiente, lugur mas grands - mojer concéntroción de ruido, muchos me freguntabon qus o lo ive tenge en los ados y que pare cia extrongero pen yo Les explique, of me entendierón y de esa formo empecé a tenex nuevos 3 migos. Er esa misma epaxa todavia seguíz.

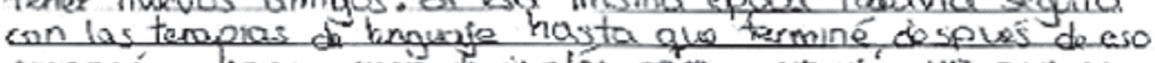
empecé a hocer curso de ingles para aprender yo ques el idioma universol.

Rie gradué de bachille y al mimn hampo como técrico del SENA me fii a los Eitados unidos a perfaccionar el idso ma por 6 moses y volvi o Culumbio orama empezar mi correra.

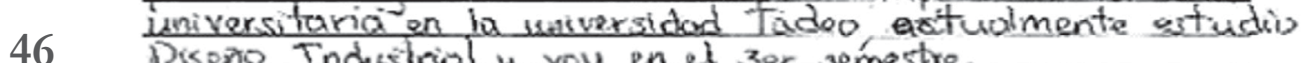
Diseño Industrial y voy en el zer sémestre

Sé que se de dificulta comunicorme owkexes ontender a vecer pens eso no as imposible ya qua yo puedo hocet muchas cosas, por ejemplo, en una eppoca fui boiturin do satsa cuando estaba en el colegio, apeendi a taner mós ritmo: toumioien puedt deferdermé con el idroma inglés

aracios a mi esfuerzo. 


\section{Appendix B. Clinton's autobiographical writing sample.}

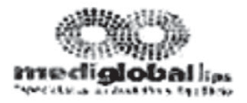

Cucintame solore ris

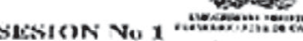

A centinuscion poudes contarnos sobre ti , puedes eumpurtix lo que tu dersecs, coulur experiencias o eseribir una trove autobiogra fin.

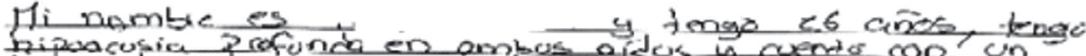

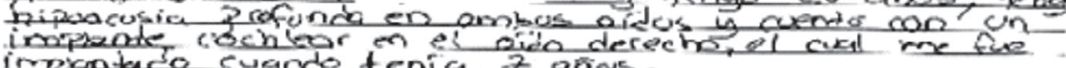

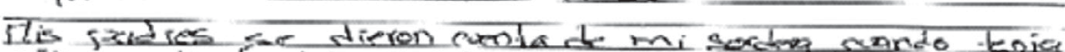

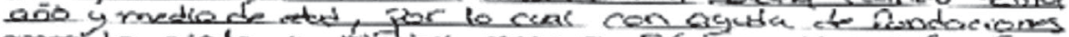

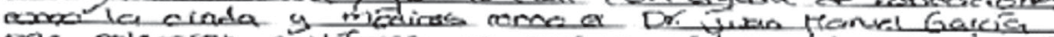

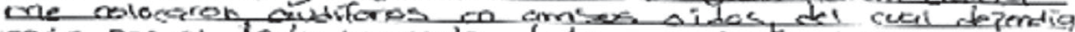

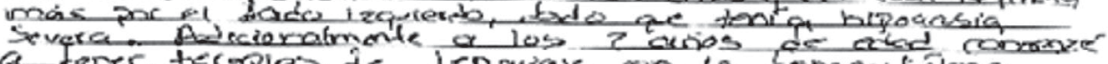

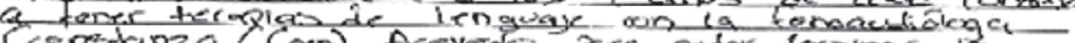

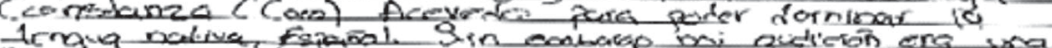

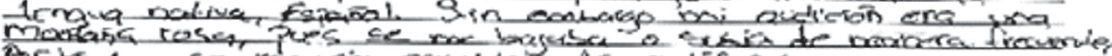

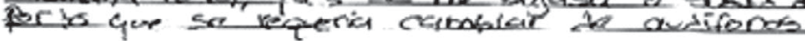

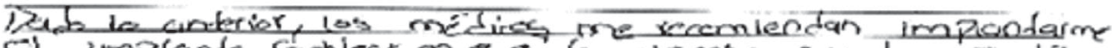

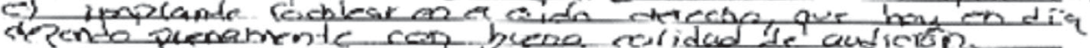

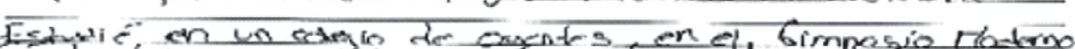

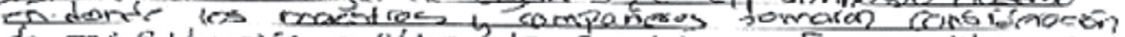

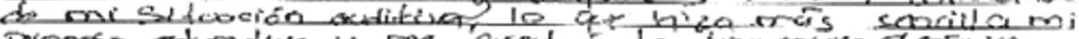

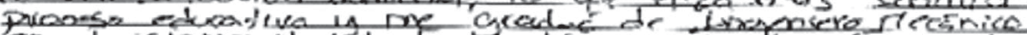

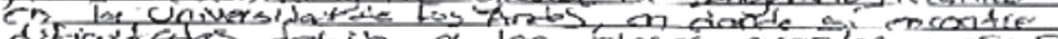

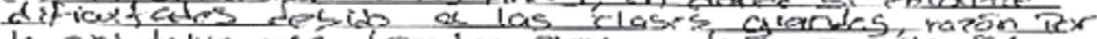

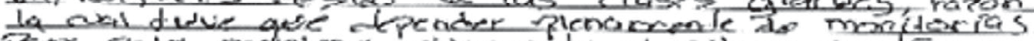

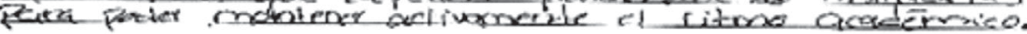

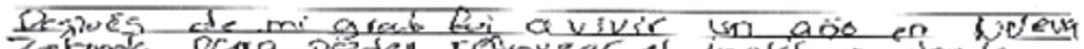

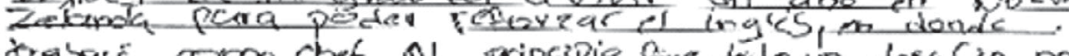

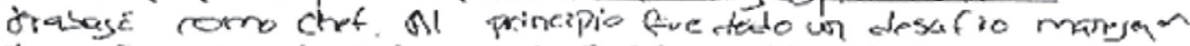
"t tngles, especialyrant en ca fronunciución, pero con la pratica, pade do minarls poco a poco. 
Rigoberto Castillo

Laura-Stefany Flórez-Martelo

\section{Appendix C. Excerpts from group interview [unedited]}

Entrevistador: Bueno chicos ahora voy a hacerles una pregunta sobre el área de inglés.

Volvemos al inglés, ¿ sí? ¿Les parece?

Clinton: yes, back to English

Interviewer: I would like you to narrate a negative experience that you had in an English class? Did you understand the question yeah? the most negative like...

Clinton: well... a very bad negative experience that I had was when the teacher decided, well two negative experiences. The number one, when the teacher decided to make a walk. $b$.. among the people when I have to keep a conversation with a person that person speaks English so slow and not vocalizing the mouth, I can't get what the person is talking about. And the second one is the track when the teacher puts a [sound] track. I have to say the teacher that I am not going to understand anything, I prefer that if we go to other room, I can connect my special devices to the computer and in this way I can understand better.

Interviewer: And the teacher did?

Clinton: Hmm sometimes, not always because, the teacher prefers puts is closer.

Clinton: well, when I think when teacher, in that moment, the teacher was.. talk, talk, talk all the time, and all my classmates understand,

Teacher become furious because they did not understand, and he continues talk, talk, and I didn't understand anything, and I wanted go out but I can't because the teacher came to the door.so, it was scared for me but in general.

Clinton: When I see a track transcription. I can understand 100\% of the conversation, because I am reading but I had like a homework like a practice listening lot of tracks and I can do improve my skills to listen the tracks, anyway, it still will be difficult.

Interviewer: Yes, the difficulties are always there no? Ok... I would like to ask you also, well, you finished the university and you are?

Edison: I' $m$ in third semester

Interviewer: so English is mandatory, in both? You have to attend English classes?

Edison: Yes, and English is mandatory, in both.

Interviewer: ¿Como se siente con respecto a la excepción de las pruebas de inglés en los exámenes nacionales para personas en condición de discapacidad?

Edison: Me parece que es una discriminación pues ellos no saben de qué es capaz la persona, que puede hacer, o sea hablar, escuchar, todo, asi que tenemos el derecho de presentar todo, todo lo que está abí.

Ludwig: Deberian tratarte en iguales condiciones al resto de los demás que presentan la prueba, Además deberian garantizar que estés en el ambiente adecuado para presentarla. Debes seguir insistiendo en que te permitan presentar la prueba sin limitaciones, ni impedirte competir a un mismo nivel con personas que no tengan ningún tipo de discapacidad.

HOW Journal 


\section{Appendix D. Signed consent.}
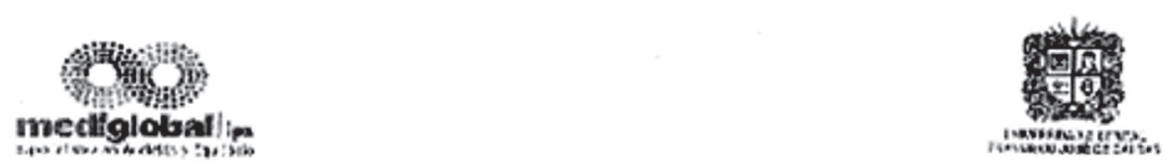

Bugota, 25 du Seplicmbre de $20 \% 8$

Aprociades pasticipantes:

A continuación se encuestra una breve dexcripción de le investigución a ruslizar, por faver lea el documents compleiamente y si ticne olguna preganta no duk cu monifestaria.

El objetivg de la invertipocisin titulada "I cannot hear but you do not listen! Unveiling: IIard of Henrings Experiences and Perspectives "Townrd ELL" con su Iruduceión cu esjafint No ojgo pero tú no cscuchas! Dovelando las experiocins y persplectivas do hjpoocusieus sobro cl sprendiraje do inglés.

Fo el do morrar las perspectiva y experioncins que tenemus como hiposcusices a la hora de morender uns lenyin extranjern como el inglés, oomo uria forrins de relatar a la coununidud atudémiç cuáles sôn nueștras necesidadss reaies en este contoxto, las diffeultades a las que nos entrentamos, como nos sentimos, para que otas puedan entender un poco astas reolidodes.

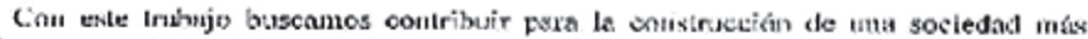
inclusiva y smpática, un seciedad con más zencentimiento de nuestra condición. por esta rwim, para mi es un honor invitarlus a participar en este proceso que contara con 3 wisiones

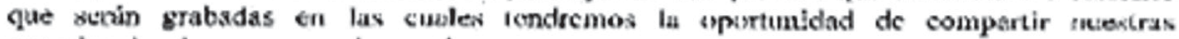
cxpóriencias de manerk cral y escrita..

listas seviconey se llevaran a cabo en las uficinas en MFDIGI.OBAL I.P.S. ubioada en ta Calle $90 \mathrm{No}$ in A-49 tome Bambú en la ciudad de Bugatá. Mediglobal ez una Institución que de mancre amable bs apoyuda esta investigación proporcionsindones ol expau:io y la colateoreción para que este proycero sca una realidad.

Fin tste: santido, solicito de mancta atenta su parlieipsticin, puntualidad y compromim duranles cil proceso pata el cual se sstublecerín umas foxhss acordadas cntto los purticipantes.

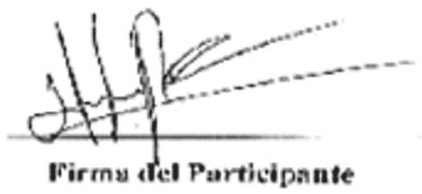


Rigoberto Castillo

Laura-Stefany Flórez-Martelo

Appendix E.

Mi fumilia me ve

como ures peoroce muz resiliente, acruve no

ester may criencido re mis' coparivtode

percibe que mis sueños

Mis companteros de clase me ven

como ofjuion qut las tiene skjades. Exterio, pues plas perciten

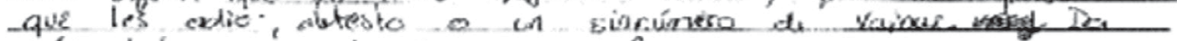

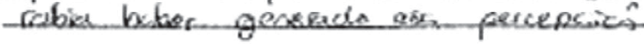

\section{Appendix F. Autobiography extract}
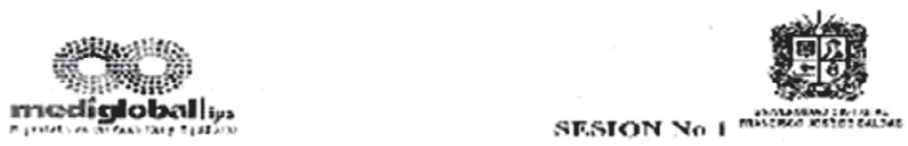

Cućntume sobre ti:

A conrinuacion pucales counarnos sobre ti, puedes compurtir to que tu tlevece, cantar experiencius a exeribit unu loreve wutobiograffa.

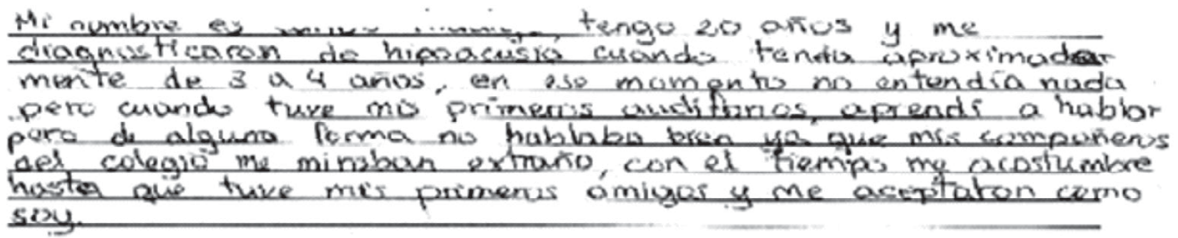

